Research Article

\title{
Ecology of Rafflesia arnoldii (Rafflesiaceae) in Pandam Gadang West Sumatra
}

\author{
Syafroni Pranata ${ }^{1}$, Sulistijorini ${ }^{2 *}$, Tatik Chikmawati ${ }^{2}$ \\ ${ }^{1}$ Plant Biology Graduate Program, Department of Biology, Faculty of Mathematics and Natural Sciences, IPB \\ University, Bogor 16680, Indonesia \\ ${ }^{2}$ Department of Biology, Faculty of Mathematics and Natural Sciences, IPB University, Bogor 16680, Indonesia
}

Article history:

Submission April 2019

Revised September 2019

Accepted September 2019

*Corresponding author:

E-mail:

sulistijorini@gmail.com

\begin{abstract}
Pandam Gadang has tropical forests which become the habitat of Rafflesia (Rafflesia arnoldii), which grows as a parasite of Tetrastigma (Vitaceae). Study on R. arnoldii is needed since its population continuously decreases as a result of habitat destruction of its host. The aim of the study was to determine habitat conditions, vegetation structure, and characteristics of the host species of Rafflesia; to identify environmental factors, and determine the Rafflesia habitat suitability in Pandam Gadang Koto Tinggi Village, West Sumatra. Analysis of vegetation in the habitat where Rafflesia grows using a circular plot. The number of individuals Rafflesia found was recorded and completed with observations of its morphology. Microclimate measurements were carried out together with data collection in the field. Flower morphological analysis was descriptively presented. Environmental parameters were-processed with Canoco software 4.56 using Canonical Correspondence Analysis. Habitat suitability was analyzed using Maximum Entropy. The 17 Rafflesia individuals found on Pandam Gadang were R. arnoldii, known as "Cendawan Biriang", living parasitically on Tetrastigma leucostaphylum. The results of analysis of vegetation in the Rafflesia habitat showed that there were 250 individual plants consisting of 42 species and 21 genera. Seedlings most dominant was Lauraceae, belt was dominated by Moraceae, Meliaceae, and Euphorbiaceae. Trees were dominated by Euphorbiaceae, Moraceae, and Meliaceae. Existence and survival of $R$. arnoldii depended on soil $\mathrm{pH} 7-7.8$, environmental humidity 83-91.8 \%, and distance from the nearest river 3-27.8 $\mathrm{m}$.
\end{abstract}

Keywords: Holoparasite, maximum entropy, Rafflesia arnoldii, Tetrastigma leucostaphylum

\section{Introduction}

Rafflesia is one of the Indo-Malesian plant genus that can be found in Malaysia, Indonesia, and the Philippines. 12 Of the 25 recorded species of Rafflesia are found in Indonesia. This plant distributes in Sumatra, Java and Borneo Islands [14]. Rafflesia arnoldii is one of the species recorded in Sumatera, and listed in the International Union for Conservation of Nature (IUCN) Red List Categories and has been assigned as Vulnerable (VU) [1, 2].

Rafflesia is a unique plant as it only consists of generative organs in the form of flowers. Male and female flowers are found in different individuals [2, 3]. Rafflesia lives as holoparasite [3, 4, 5] and attached to the host plant through an organ called haustoria which has a root-like function [1]. The host belongs to the genus Tetrastigma (Vitaceae) which is liana [6]. The existence of the host plant plays significant role in the presence of Rafflesia. One of the factors that threaten the scarcity of Rafflesia is the lack of knowledge of the community to recognize host plants $[7,8]$. In addition, natural disturbances such as landslides and floods have caused habitat damage, so that reduce the population of Rafflesia [6].

Rafflesia grows well in the forest floor of West Sumatera. There are three species in West Sumatra, named $R$. arnoldii, $R$. haseltii, and $R$. gadutensis $[1,9,10]$. In the last three years, $R$. arnoldii 
was recorded in Lima Puluh Kota, Koto Tinggi Village, Gua Aie Singkek Nagari Pandam Gadang. R. arnoldii was found in primary forest in Pandam Gadang which is ideal for its existence [11].

However, characteristics of the population and environmental conditions that support the occurrence of Rafflesia in this region has not been studied. Therefore, further studies on both aspects are crucial to support the conservation and survival of Rafflesia. This study aims to: (1) analyze habitat conditions and vegetation structure in the population of Rafflesia in the Pandam Gadang; (2) identify the environmental factors of $R$. arnoldii in Pandam Gadang; (3) determine the conservation area in situ using Maximum Entropy (MaxEnt) analysis. The results of this study are expected to be used as baseline data for conservation and development of the Rafflesia on the Pandam Gadang.

\section{Material and Methods Data collection}

The research was conducted in Nagari Pandam Gadang, Gunuang Omeh District, Lima Puluh Kota Regency ( $0^{\circ} 02^{\prime} 14.816^{\prime \prime}$ S $100^{\circ} 18^{\prime}$ 03.246" E), West Sumatra Province from August 2018 to March 2019. Purposive sampling was employed in the fieldwork based on the presence of $R$. arnoldii with a circular plot (Figure 1) [9, 12,13$]$. The circular plot was used by three subplots set up according to $R$. arnoldii as center point. In each plot, the plants in vegetation were divided according to the growth level of vegetation from trees, belt and seedling. The vegetation composition was observed based on the size of the main stem diameter including trees $>10 \mathrm{~cm}$, belt $2-10 \mathrm{~cm}$ and seedlings $<2 \mathrm{~cm}$ [14]. Subplots for tree vegetation are

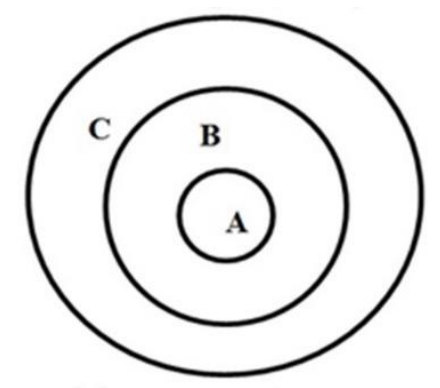

Figure 1. Scheme of observation of Rafflesia [18]. A= 0.001 ha $(r=1.785 \mathrm{~m})$ for seedlings, $B=$ 0.01 ha $(r=5.65 \mathrm{~m})$ for belta, $\mathrm{C}=0.1 \mathrm{ha}(\mathrm{r}$ $=17.85 \mathrm{~m}$ ) for trees individuals are recorded as biotic data. The abiotic data includes air temperature, soil temperature, air, and soil humidity, wind speed and light intensity. Measurements were made with 4 in 1, soil tester and thermometer. Elevation and geographic coordinate data were collected using a distance measuring instrument (meter) and Global Positioning System (GPS). The distance of Rafflesia with the nearest water source was measured manually using a meter.

\section{Data analysis}

Biotic data was processed by vegetation analysis including Relative Frequency (RF), Relative Dominance (RDo), and Relative Density (RD). Important Value Index (IVI) is calculated using the following formula:

$$
\mathrm{IVI}=\mathrm{RF}_{(\mathrm{i})}+\mathrm{RDo}_{(\mathrm{i})}+\mathrm{RD}_{(\mathrm{i})}
$$

The individual data of $R$. arnoldii consists of morphology, size, number, and developmental phase were analyzed in a descriptive way. In order to determine the environmental factors that affect the survival of Rafflesia, Principal Component Analysis (PCA) using Canoco version 4.56 was done. Habitat suitability maps were created using the Maximum Entropy (MaxEnt) version 4.01 program, using coordinates and exploration results. Environmental data were downloaded from Worldclim.org and Fao.org with a resolution of 1 km (30s) [15]. Distributional map of R. arnoldii in Pandam Gadang created using ArcGIS 10.3.

\section{Results and Discussion \\ The population of Rafflesia arnoldii}

Local people in Pandam Gadang name R. arnoldii as "Cendawan Biriang". A total of 17 individuals from three populations was found in Pandam Gadang in which 4 individuals in the dead condition in the form of blossoms and buds (knop). Twelve individuals were found to grow in the host root section (Table 1). There were 8 individuals with intact closed knop that were covered with bracts, knop with bracts conditions which were slightly exposed to the top 3 individuals and 1 dead knop. The largest knop diameter is 21.66 $\mathrm{cm}$, still intact and covered with bracts, growing in the host root (Tetrastigma leucostaphylum), while the smallest knop is $8.59 \mathrm{~cm}$ growing at the base of the host with intact conditions covered by bra- 
Table 1. Individuals Conditions in a population of Rafflesia in Pandam Gadang

\begin{tabular}{|c|c|c|c|c|c|}
\hline Population & Individuals & $\begin{array}{l}\text { Diameter } \\
(\mathrm{cm})\end{array}$ & $\begin{array}{l}\text { Height } \\
(\mathrm{cm})\end{array}$ & $\begin{array}{c}\text { Grow Places at } \\
\text { Tetrastigma }\end{array}$ & Conditions Individuals \\
\hline \multirow[t]{5}{*}{ I } & 1 & 10.51 & 4.5 & Roots & $\begin{array}{l}\text { Knop with brachtea slightly } \\
\text { open at the top }\end{array}$ \\
\hline & 2 & - & - & Roots & Former blossoming \\
\hline & 3 & - & - & Roots & Former flowers bloom \\
\hline & 4 & 18.79 & 14.5 & Roots & Knop fully enclosed brachtea \\
\hline & 5 & - & - & Roots & Former flower bloom \\
\hline \multirow[t]{4}{*}{ II } & 6 & 9.55 & 6 & The base of the stem & Knop fully enclosed brachtea \\
\hline & 7 & 10.19 & 5 & Roots & Knop fully enclosed brachtea \\
\hline & 8 & 19.75 & 16 & Roots & Knop fully enclosed brachtea \\
\hline & 9 & - & - & Roots & Former flower bloom \\
\hline \multirow[t]{8}{*}{ III } & 10 & 14.01 & 9 & Roots & Knop covered with brachtea \\
\hline & 11 & 21.66 & 14 & Roots & $\begin{array}{l}\text { Knop with a little open at the } \\
\text { top }\end{array}$ \\
\hline & 12 & 14.33 & 11 & The base of stem & Knop is covered with brachtea \\
\hline & 13 & 9.87 & 3.8 & Roots & Knop with a little open top \\
\hline & 14 & 48.72 & 26 & Roots & $\begin{array}{l}\text { Flower blooms begin to wither } \\
\text { and black }\end{array}$ \\
\hline & 15 & 20.70 & 7.8 & The base of the stem & Whole knop \\
\hline & 16 & 8.59 & 5.7 & The base of the stem & Whole knop \\
\hline & 17 & 8.28 & 4 & The base of the stem & Whole knop \\
\hline
\end{tabular}

Table 2. Vegetation found in habitat Rafflesia arnoldii

\begin{tabular}{lccc}
\hline $\begin{array}{c}\text { Vegetation } \\
\text { type }\end{array}$ & $\begin{array}{c}\text { Number of individ- } \\
\text { ual }\end{array}$ & $\begin{array}{c}\text { Number } \\
\text { of species }\end{array}$ & Dominant family \\
\hline Seedlings & 49 & 8 & Lauraceae \\
Belts & 102 & 25 & Moraceae, Lauraceae, Meliaceae, Euhporbiaceae \\
Trees & 99 & 32 & Euhorbiaceae, Moraceae, Meliaceae \\
\hline Total & 250 & 42 & \\
\hline
\end{tabular}

cts. Among the 17 individuals, there were individual blooms that began to wither and blacken with flower organs still complete. Based on information from the local community, it is estimated that flowers begin to wilt after $5-6$ days. The distance of the population of $R$. arnoldii from the nearest water source (river) varies between 3.8 to $27.4 \mathrm{~m}$. The populations near the river are susceptible to floods and landslides.

\section{Vegetation in Rafflesia arnoldii habitat}

Observation of vegetation from three subplots revealed 42 species of plants belong to 21 genus. In this type of vegetation, 49 seedlings were found belong to 8 species dominated by member of Lau- raceae. A number of 102 individuals consisted of 25 species were recorded for the belt, consists of Moraceae (4 individual), Euphorbiaceae (3), Meliaceae (2), and Lauraceae (2). A number of 99 individuals from 32 species were recorded for tree, which consists of Euphorbiaceae (7), Moraceae (5), and Meliaceae (5) (Table 2).

The seedings and belts were dominated by coffee (Coffea canephora) with IVI values at $107.81 \%$ for seedlings and $52.74 \%$ for belts. The dominant tree species is kayu surian (Toona surenii) with IVI is $44.97 \%$ (Table 3 ). The higher IVI value indicated that the species has a high level of tolerance to the environment and population of this type [9] and indicates that the species has high 

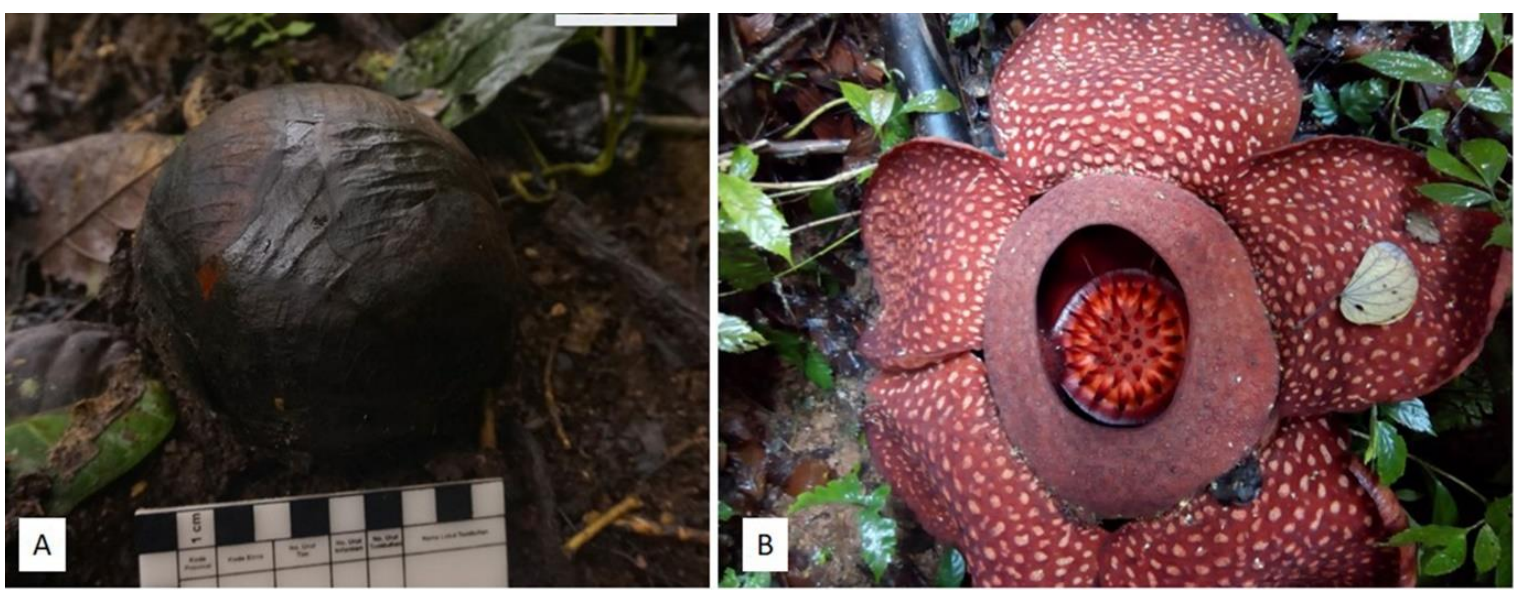

Figure 2. Morphology of R. arnoldii flower. Young knop still completely enclosed within bracts (A) and flowers in full bloom (B). Scale bar $A=3 \mathrm{~cm}, \mathrm{~B}=10 \mathrm{~cm}$

Table 3. Five species of plants with the highest Importance Value Index in the habitat of Rafflesia arnoldii in Pandam Gadang

\begin{tabular}{clcc}
\hline Vegetation & Species & Family & INP (\%) \\
\hline \multirow{2}{*}{ Seedings } & Coffea canephora & Rubiaceae & 107.81 \\
& Laportea stimulans & Urticaceae & 55.81 \\
& Villebrunea rubescens & Urticaceae & 50.10 \\
& Cinamomum burmannii & Lauraceae & 24.33 \\
& Ficus disticha & Moraceae & 23.83 \\
\hline \multirow{2}{*}{ Belta } & Coffea canephora & Rubiaceae & 52.74 \\
& Toona surenii & Meliaceae & 34.11 \\
& Laportea stimulans & Urticaceae & 24.62 \\
& Cinnamomum burmanii & Lauraceae & 18.45 \\
& Ficus ampelas & Moraceae & 14.53 \\
\hline \multirow{2}{*}{ Trees } & Toona surenii & Meliaceae & 44.97 \\
& Shorea sp. & Dipterocarpaceae & 26.24 \\
& Aglaia argentea & Meliaceae & 25.94 \\
& Ficus fistulosa & Moraceae & 16.08 \\
& Macaranga gigantea & Euphorbiaceae & 13.06
\end{tabular}

dominance in Rafflesia population in Pandam Gadang.

\section{Abiotic Factors of Rafflesia arnoldii habitat}

Three populations of $R$. arnoldii were found at 800 to $1,024 \mathrm{~m}$ asl. Air humidity range between 83-91.8\%. This condition probably caused by the dense canopy cover which could maintain the air humidity. The soil has a $\mathrm{pH}$ with a range between 7-7.8 and classified as neutral to alkaline, while soil is moist ranges with range of slackness from 65 to $97.4 \%$. The highest humidity is found in the habitat of the second population with a value of
91.3-97.4\%. Measurement of the distance of population to water sources ranging from 3 to $27.8 \mathrm{~m}$. The third population is the furthest from the river at distance range from 26 to $27.8 \mathrm{~m}$, while the first population has the nearest distance from 3 to 3.8 $\mathrm{m}$. The result was reported contrast to other locations $R$. arnoldii grows at lower altitude of 490558 masl, has relatively acidic soil pH of 5.5 [12].

The results of abiotic parameters observation are presented in Table 4 . Light intensity varies from 130 to 803 lux, with the first population has the highest light intensity (800-803 lux) and the third population has the lowest (130-137 lux). The 
Table 3. Physical parameters of the environment in Pandam Gadang

\begin{tabular}{lccc}
\hline \multirow{2}{*}{ Abiotic factors } & \multicolumn{3}{c}{ Population } \\
\cline { 2 - 4 } & 1 & 2 & 3 \\
\hline Elevation (m asl) & $800-806$ & $1.003-1.010$ & $1.021-1.024$ \\
ambient temperature $\left({ }^{\circ} \mathrm{C}\right)$ & $23.4-25.8$ & $21-23.2$ & $19.1-21$ \\
Humidity (\%) & $85-86.6$ & $83-87.1$ & $86.3-91.8$ \\
Wind speed (m / s) & $1.5-2$ & 0 & 0 \\
$\mathrm{pH}$ land & $7-7.2$ & $7-7.4$ & $7-7.8$ \\
Soil moisture (\%) & $65-68$ & $91.3-97.4$ & $68-71$ \\
Soil temperature $\left({ }^{\circ} \mathrm{C}\right)$ & $19.4-22$ & $20-23.2$ & $19-22.1$ \\
Light intensity (lux) & $800-803$ & $200-208$ & $130-137$ \\
The distance of population from the river (m) & $3-3.8$ & $3.6-4$ & $26-27.8$ \\
\hline
\end{tabular}

Table 5. Plant species climbed by Terastigma leucostachyum in Pandam Gadang

\begin{tabular}{cll}
\hline Vegetation & \multicolumn{1}{c}{ Species } & \multicolumn{1}{c}{ Family } \\
\hline Seedlings & Laportea stimulans & Urticaceae \\
& Coffea canephora & Rubiaceae \\
Belts & Campnosperma sp. & Anacadardiaceae \\
Trees & Laportea stimulans & Urticaceae \\
\hline
\end{tabular}

Table 6. Fauna around the Rafflesia population in Pandam Gadang and their activities

\begin{tabular}{lll}
\hline Scientific Name & Local Name & Activities and Findings \\
\hline Sesarmidae (geosearmid) & Kepiting & walk in litter \\
Sus scrofa & Babi Hutan / kondiak & create nest and the traces of \\
Macaca fascicularis & Karo & climbing trees around population \\
Presbytis melalophus & Simpai & climbing trees around population \\
Ratufa affinis & Tupai & climb a tree around the population \\
Ratufa bicolor & Tupai & climb the tree supporting host \\
Macaca nemestrina & Baruak & climb a tree around the population \\
Drosophila colorata & Lalat & wilted on flowers \\
Chrysomya megacephala & Lalat & wilted on flowers \\
Sarcophaga haemorrhoidalis & Lalat & withered on flowers \\
\hline
\end{tabular}

difference in light intensity in each population is caused by the presence of land clearing, where light emitted by the sun directly into the forest floor increases ambient temperature. The results obtained indicate that third population has the lowest light intensity. It can be assumed that $R$. arnoldii prefers shelter, this also evidenced by the highest number of 8 individuals founded (Table 1). Light intensity on of the physical factors of the environment that role in the proliferation of habitat Rafflesia [14, 13], and helps the development or $R$. arnoldii [12].

\section{Morphology of Rafflesia arnoldii}

Flower of Rafflesia consists of two phases, in buds termed as knop and fully bloom (Figure 2A).
Knop is the initial stage of development of flowers which is globular and has brown bracts. The bracts protect the young flower by covering the internal organs before they starting to bloom. The young knop will develop to adult knop marked by its size that is getting bigger, and it the bracts began to open and the strands of the perigone lobe change the color to pink or orange. The adult knop has a complete flower section can be distinguished between the inside and outside. The second stage is fully blooming flower show distinct five perigone lobes (Figure 2B). The diameter of fully blooming flower of $R$. arnoldii has $64.65 \mathrm{~cm}$ diameter with five intact perigone lobes strands and there are white patches on the surface. This result consistent by the research who reported that $R$. arnoldii had 


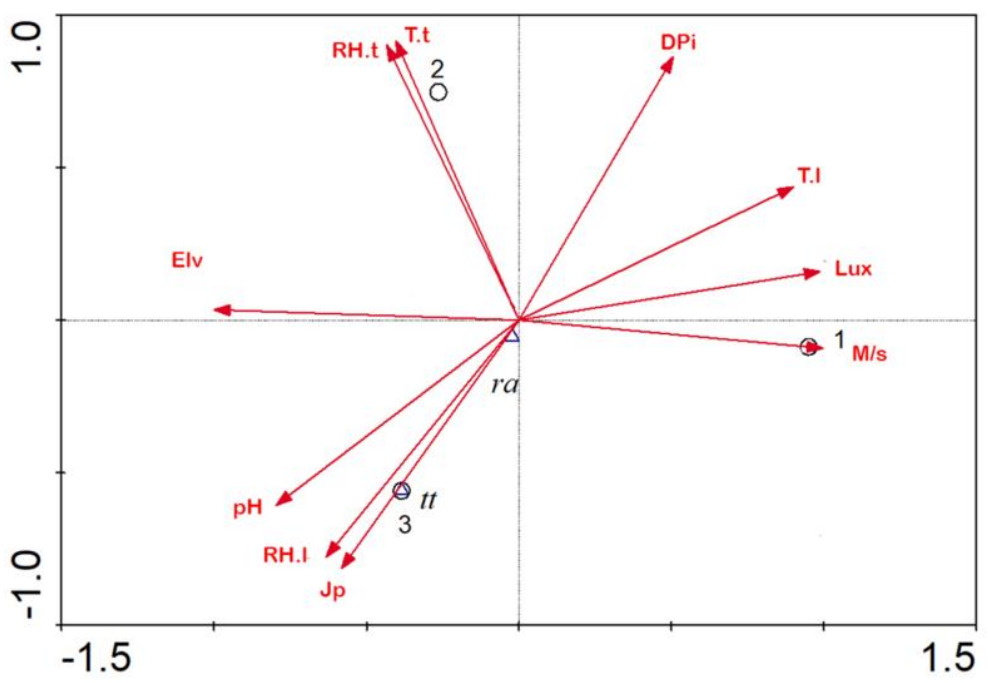

Figure 3. Ordinary Canonical Correspondence Analysis (CCA) population in Padang Pandam shows the first and third axis of environmental factors. Elv: Elevation, Dpi: host plant diameter, T.l: environmental temperature, RH.l: environmental humidity, M/s: wind speed, $\mathrm{pH}$ : soil $\mathrm{pH}$, T.t: soil moisture, T.t: soil temperature, Lux: light intensity, Jp: distance of population from the river, tt: T. leucostaphylum, ra: $R$. arnoldii

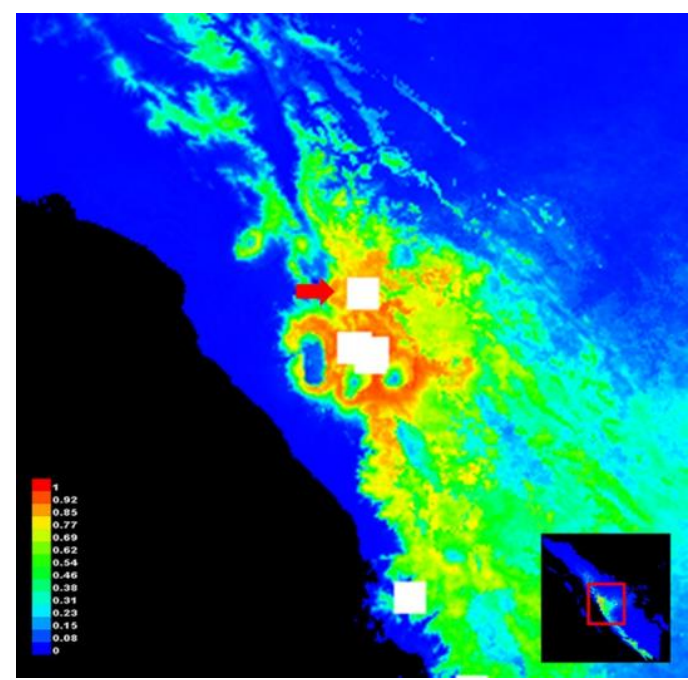

Figure 4. Habitat suitability modeling R. arnoldii at Pandam Gadang (red arrow)

small white (wart) patches on the perigone lobe, and was the largest size compared to the other Rafflesia species [1, 2].

Based on the recent observation, the strands of the perigone lobe have the largest and smallest widths which are $28 \mathrm{~cm}$ long and $24 \mathrm{~cm}$ wide and $25 \mathrm{~cm}$ long and $22 \mathrm{~cm}$ wide. The observed perigone tube height ranging from 22 to $23.5 \mathrm{~cm}$ while disk height ranging from 11 to $13 \mathrm{~cm}$ bearing 51 processes.

\section{Host plants: Tetrastigma leucostaphylum}

Hosts plant recorded during the study is T. leu- costaphylum with diameter at breast height (DBH) at the smallest class at $1.73-1.88 \mathrm{~cm}$, while the largest class at $6.13-6.73 \mathrm{~cm}$. Tetrastigma leucostaphylum usually reproduces generatively but vegetative host proliferation was also recorded during the study, covering the stem and branches of the young shoots of the host stem. Host plant always climb trees right in the population $R$. arnoldii. The results of the identification of host tree species T. leucostaphylum originated in more than one species (Table 5). The host tree is usually the closest one to T. leucostaphylum. Therefore, it is assumed the host tree play an important role in sta- 


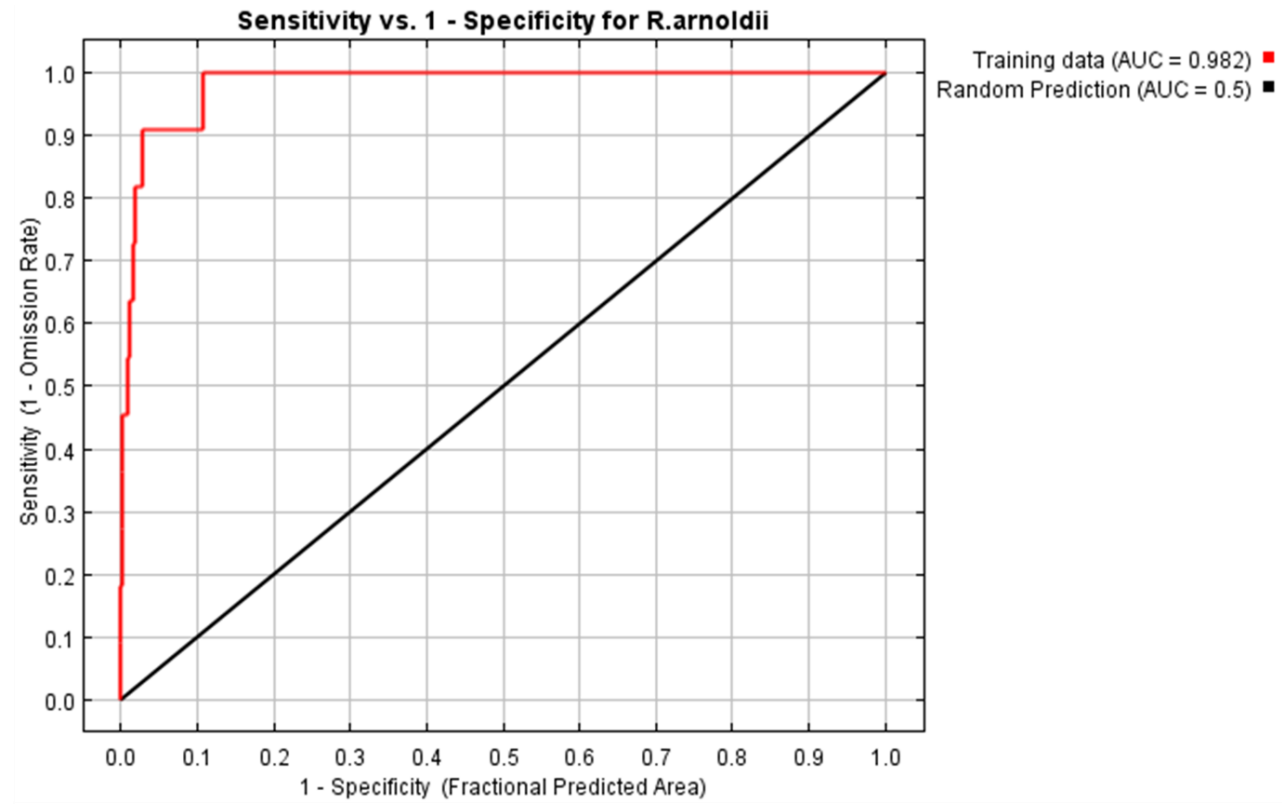

Figure 5. Area Under the Curve (AUC) value in modeling R. arnoldii habitat

Table 7. Environmental factors and its contribution in the habitat of $R$. arnoldii in Pandam Gadang

\begin{tabular}{clc}
\hline Variable & \multicolumn{1}{c}{ Description } & Percentage of Contribution (\%) \\
\hline bio19 & Precipitation of coldest quarter & 42.7 \\
chy3 & Light intensity in March 2018 & 16.9 \\
chy12 & Light intensity December 2018 & 13.1 \\
bio15 & Precipitation seasonality & 12.7 \\
bio7 & Temperature annual range (bio5-bio6) & 4.1 \\
chy2 & Light intensity in February 2018 & 3.8 \\
bio2 & Maximum and minimum temperature ranges & 2.9 \\
\hline
\end{tabular}

bilizing the ambient temperature, humidity and light intensity of the $R$. arnoldii habitat. The ability of the host to wrap (belt) around the surrounding plants that forms the second and third associations can form a dense canopy around the population, the light will be blocked by the canopy entering [2].

The lack of public knowledge about $R$. arnoldii host plant is one of the threats to existence. In one sub-population, the host has been found as a dead plant because it has been cut down by the locals. The breakdown of the stem or host root infected with $R$. arnoldii will certainly disrupt the development of $R$. arnoldii directly because it will cause the cessation of nutrient supply from the host $[16,13]$.

\section{Fauna activity}

From the observation, six large mammals, two rodents (Rodentia) and three insects were found
(Table 6). The foul aroma of $R$. arnoldii invite the insects and ants. Various types of insects such as flies (Drosophila colorata, Chrysomya megacephala, Sarcophaga haemorridalis) were found and actively visited the late flowers. Other insects such as black ants (Euprenolepisare sp.) were found on the dead knop and considered as source of deadly threats to knop. The previous research stated that black ants were found on the bractea of the dead knop [17].

\section{Principal Component Analysis (PCA)}

Based on PCA, the presence of Rafflesia in Pandam Gadang is largely due to some environmental factors. There are three environmental factors which are positively correlated which include the distance of the population from the river (Jp), humidity (RH.l), and soil $\mathrm{pH}(\mathrm{pH})$ (Figure 3). The presence of individuals at one ordinance with certain environmental parameters shows the influ- 
ence environmental factors on the occurrence of the plant [18].

\section{Habitat suitability model of Rafflesia arnoldii}

Land clearing such as deforestation found in two populations of $R$. arnoldii is a threat to quality of habitat for $R$. arnoldii. The map of habitat suitability model of $R$. arnoldii generated from the MaxEnt program (Figure 4) and considered as still very good. This also indicated by the results of the data used are very suitable, with the position of the blue line on the black line (line with random data). The color produced in the population is red to near red which shows a value close to 1 so that the probability value and suitability of modeling a habitat are said to be good [18]. The Maximum Entropy model produced a habitat suitability map named Area under the Curve (AUC) with a value at 0.982 that approaches 1 indicates the suitability of habitat $R$. arnoldii very well (Figure 5). AUC analysis showed a number that approaches one has a prediction model with good probability. After the previous research mentioned that variables were used to predict and contribute to each habitat $[19,20]$.

Jacknife test was used to determine the most important environmental factors for the existence of $R$. arnoldii. The main variable that significantly affect the type of MaxEnt modeling is the coldest rainfall (high) at $42.7 \%$ followed by light intensity (Table 7). The relationship between environmental factors and species in habitat a can be seen by contribution of each parameter from the results of MaxEnt analysis [21, 22].

\section{Conclusion}

Rafflesia species at the study site is $R$. arnoldii R. Br. known by the local as Cendawan Biriang. The only host plant recorded is T. leucostaphylum. The results of vegetation analysis in $R$. arnoldii habitat in Pandam Gadang showed that 260 individuals belong to 43 species and 22 genus have been recorded. The seedlings are dominated by Lauraceae, belts by Moraceae, Meliaceae, Euphorbiaceae, and Lauraceae, while trees are dominated by Euphorbiaceae, Moraceae, and Meliaceae. Environmental factors that influence $R$. arnoldii populations are soil $\mathrm{pH}$ 7-7.8 (pH), humidity 83-91.8\% (RH.l) and distance of the population from the river 3-27.8 $\mathrm{m}(\mathrm{Jp})$. The level of suitability habitat of $R$. arnoldii in the study site show that habitat models were still very good.

\section{Acknowledgment}

The author is grateful to the West Sumatra Provincial Government Office for National Unity and Politics, and the Natural Resources Conservation Center, which has given research permits. The author would like to thank the field survey team who helped during the investigation of Uda Rico, Rido Affan, Zulhendra, and Bima Firmantara.

\section{References}

1. Nais J (2001) Rafflesia of the World. Kinabalu, Sabah Parks.

2. Susatya A (2011) Rafflesia pesona bunga terbesar di dunia. Jakarta, Pustaka Nasional

3. Mursidawati S, Irawati (2017) Biologi konservasi Rafflesia. Jakarta, LIPI Press.

4. Barcelona JF, Manting MME, Arbolonio RB et al. (2014) Rafflesia mixta (Rafflesiaceae), a new species from Surigao del Norte, Mindanao, Philipines. Phytotaxa 174 (5): 272 - 278. doi: 10.11646/phytotaxa.174.5.3.

5. Nikolov LA, Endress PK, Sugumuran M et al. (2013) Developmental origins of the world's largest flower, Rafflesiaceae. Proceeding of the National Academy of Sciences 46 (110): 18578 - 18583. doi: 10.1073/pnas.1310356110.

6. Hidayati SN, Walck JL (2016) A review of the biology of Rafflesia: what do we know and what's next? Botanic Garden Bulletin 19 (2): 67 - 78. doi: 10.1177/2F1940082918796011.

7. Peters RF, Ting YY (2016) Protection of Rafflesia through the appreciation of the Dusun's indigenous knowledge; A preliminary case study at Poring-Sabah. Journal of Tropical Biology and Conservation (13): 27 - 42.

8. Pranata S, Sofiyanti N, Fitmawati (2016) Karakterisasi morfologi Rafflesia dan inangnya di kawasan Suaka Margasatwa Bukit Rimbang Bukit Baling Kabupaten Kampar Provinsi Riau. Jurnal Riau Biologia 1 (2): 107 - 112.

9. Rahma Y, Arma SP, Syamsuardi (2017) Analisis vegetasi habitat Rafflesia Gadutensis Meijer. di Taman Hutan Raya Dr. M. Hatta, Kota Padang. Journal of Biological Sciences 4 (2): 196 201.

10. Whitten T, Damanik SJ (2012) Ecology of Sumatra. Washington DC, Tuttle Pub.

11. Metrizal (2018) Indahnya Goa Aie Singkek dan penemuan Rafflesia di Koto Tinggi. http://www.impiannews.com/ 2018/01/indahnya-goa-aie-singkek-danpenemuan.html. Accessed date: 2018. 
12. Ramadhani DN, Setiawan A, Master J (2017) Populasi dan kondisi lingkungan Rafflesia arnoldii di Rhino-Camp Resort Sukarajan atas Taman Nasional Bukit Barisan Selatan (TNBBS). Jurnal Sylva Lestari 5 (2): 128 - 141.

13. Simamora JM, Hikmat A, Zuhud EAM (2017) Pengaruh faktor biotik dan fisik lingkungan terhadap jumlah individu Rafflesia meijerii di Taman Nasional Batang Gadis. Media Konservasi 22 (1): $35-41$

14. Priatna DR, Zuhud EAM, Hadi S, Alikodra (1989) Kajian ekologis Rafflesia patma Blume di Cagar Alam Leuweung Sancang Jawa Barat. Media Konservasi 2 (2): 1 - 7.

15. Elith J, Phillips SJ, Hastie T et al. (2011) A statistical explanation of MaxEnt for ecologists. Diver Distributions 17 (11): 43 57. doi: 10.1111/j.1472-4642.2010.00725.x.

16. Kedri FK, Hamzah Z, Sukri NS et al. (2018) Distribution and ecology of Rafflesia in Royal Belum State park, Perak, Malaysia. International Journal of Engineering \& Technology 7: 292 - 296. doi: 10.14419/ijet.v7i2.29.13335.

17. Ali MA, Agus H, Zuhud EA (2015) Kajian karakteristik habitat Rafflesia (Rafflesia patma Blume) di cagar alam Bojonglarang Jayanti, Cianjur, Jawa Barat. Media Konservasi 20 (1): 9 - 14.

18. Hidayat S, Juhaeti T (2013) Asosiasi Alstonia spp. di Taman Nasional Ujung Kulon. Bionatura 15 (1): 44 - 48.
19. Esfanjani J, Ghorbani A, Chahouki MAZ (2018) MaxEnt modelling for predicting impacts of environmental factors on the potential distribution of Artemisia aucheri and Bromus tomentellus-Fustuca ovina in Iran. Polish Journal of Environmental Studies 27 (3): 1041 - 1047. doi: 10.15244/pjoes/76496.

20. Harsono T, Kurniawan AS, Prakasa H et al. (2016) Analisis spasial geografi dan maximum entropy untuk menentukan zona konservasi in situ pada Andaliman (Zanthoxylum acanthopodium DC.) di Sumatera Utara. Pekanbaru, Prosiding Seminar Nasional Perhimpunan Pemuliaan Indonesia (PERIPI). Pp 224 $-232$.

21. Malinikova E, Kukla J, Kuklova M, Balazova M (2013) Altitudinal variation of plants traits: morphological characteristics in Fragaria vesca L. (Rosaceae). Annals of Forest Research 56 (1): $78-89$.

22. Radnezhad H, Abari MF, Moshtaghi M, Sadeghi M (2015) Maximum entropy habitat suitability and distribution modelling of Persian Gazelle (Gazella subgutturosa). Indian Journal of Natural Sciences (5): 976 - 997. doi: 10.22120/jwb.2019.98454.1041. 
This page is intentionally left blank. 